\title{
REVITALISASI 'ALAM TERKEMBANG JADI GURU' DALAM BUDAYA BERBAHASA DI MINANGKABAU: ANALISIS PEMANFAATAN SIMBOL METAFORA DALAM PEPATAH-PETITIH MINANGKABAU
}

Yuniseffendri

Fakultas Bahasa dan Seni, Unesa

(divabunga@yahoo.co.id)

\begin{abstract}
ABSTRAK
'Alam Terkembang Jadi Guru' merupakan falsafah adat yang tumbuh dan berkembang di bumi Minangkabau (Sumatera Barat).Kedekatan masyarakat dengan alam sekitar terlihat dari kekonsistenan masyarakat dalam memandang alam sebagai sumber pengetahuan dan sebagai guru dalam menata perilaku dan perbuatan. Penelitian yang berjudul "Revitalisasi 'Alam Terkembang Jadi Guru' dalam Budaya Berbahasa di Minangkabau: Analisis Pemanfaatan Simbol Metafora dalam Pepatah-petitih Minangkabau" ini merupakan upaya pendeskripsian terhadap sejauhmana falsafah "Alam Terkembang Jadi Guru" diimplementasikan dalam kehidupan masyarakat, khususnya dalam budaya berbahasa masyarakat Minangkabau.Penelitian ini bersifat deskriptif-kualitatif menggunakan metode analisis isi (content analysis) dengan menerapkan langkah-langkah pengumpulan data, reduksi data/display data, penganalisisan data, dan penarikan inferensi sebagai prosedur penganalisisan data.Melalui penelitian ini dapat dideskripsikan kedekatan masyarakat Minangkabau dengan alam sekitar, yang tercermin dari perilaku berbahasa yang sarat dengan pemanfaatan simbol kebahasaan yang besumber dari alam sekitar. Dengan kata lain, semakin sering masyarakat menggunakan simbol tertentu yang diambil dari lingkungannya untuk menyatakan maksud sebuah tuturan, maka semakin dekat hubungan masyarakat dengan simbol tersebut. Penelitian ini diarahkan pada pendeskripsian sejauhmana kedekatan masyarakat Minangkabau dengan alam sekitar yang tercermin dalam perilaku budaya berbahasa.Dengan demikian, penelitian ini diharapkan dapat dijadikan sebagai upaya pelestarian budaya, khususnya budaya berbahasa yang khas di Sumatera Barat.
\end{abstract}

Kata kunci: Revitalisasi, pepatah-petitih, simbol metafora, alam terkembang jadi guru

\section{A. PENDAHULUAN}

Falsafah "Alam Terkembang Jadi Guru" menyiratkan bahwa segala sesuatu yang tersaji di alam semesta ini merupakan anugerah Tuhan yang dapat dijadikan sebagai pedoman dalam tatanan hidup bermasyarakat. Implementasi dari konsep 'Alam Terkembang Jadi Guru” bukan hanya dimanifestasikan dalam bentuk perhatian dan pemanfaatan alam sebagai sumber pengetahuan dan peradaban, melainkan juga tercermin dalam perilaku berbahasa. Hal ini tercermin dalam pemanfaatan simbol-simbol yang dapat merujuk pada konsep tertentu sesuai tujuan komunikasi. Keberadaan simbol dalam ungkapan kebahasaan merupakan suatu yang tidak 
bisa lepas dari aktivitas berbahasa bagi masyarakat Minangkabau. Kemampuan berpikir secara simbolik, dapat mengabstraksikan pengalamannya dalam suatu sistem yang penuh makna, sehingga memungkinkan seseorang dapat mewariskan dan mengkomunikasikan pengalaman dan pemikiran mereka pada pihak lain.

Penggunaan simbol yang bersumber dari alam sekitar, sudah menjadi kelaziman dalam budaya berbahasa di Minangkabau. Hal ini dapat dilihat dari contoh berikut:

\section{Batamu ruyuang jo baliuang}

(Bertemu ruyung dengan beliung)

Ungkapan tersebut menggambarkan tentang pertemuan (perseteruan) antara dua orang yang sama sama memiliki kekuatan. Kekuatan seseorang tersebut digambarkan melalui pemanfaatan lambang ruyuang (bagian dari pohon kelapa yang memiliki serat kasar dan keras) serta baliuang (sejenis perkakas terbuat dari besi). Sifat keras yang dimiliki oleh kedua benda tersebut dijadikan sebagai simbol untuk melambangkan pertemuan (perseteruan) antara dua orang yang sama-sama memiliki kekuatan.

Contoh tersebut menunjukkan bahwa kedekatan masyarakat dengan alam sekitarnya, mampu melahirkan bentuk tuturan yang sarat dengan simbol kebahasaan yang bersumber dari alam sekitar. Kenyataan ini mengilhami penelitian tentang sejauhmana masyarakat Minangkabau memahami alam sekitar sebagi bagian yang tidak terlepas dari budaya berbahasa. Fokus penelitian diarahkan pada upaya mendeskripsikan 'Bagaimana penggunaan simbol metafora dalam pepatah petitih Minangkabau yang bersumber dari lingkungan alam Minangkabau?; (2) Bagaimana kedekatan masyarakat Minangkabau dengan alam sekitarnya, yang tercermin dalam pemanfaatan simbol metafora dalam pepatah-petitih Minangkabau?; (3) Bagaimana keterkaitan falsafah 'Alam Terkembang Jadi Guru' dengan budaya berbahasa di Minangkabau melalui pemanfaatan simbol metafora dalam pepatah-petitih Minangkabau?. Berdasarkan masalah tersebut, tulisan ini bertujuan untuk (1) Mengidentifikasi pemanfaaatan lambang metafora dalam pepatah-petitih Minangkabau?; (2) Mengklarifikasi kedekatan masyarakat Minangkabau dengan alam sekitarnya, yang tercermin dalam pemanfaatan simbol metafora dalam pepatah-petitih Minangkabau?; (3) Menjelaskan keterkaitan falsafah 'Alam Terkembang Jadi Guru' dengan budaya berbahasa di Minangkabau melaui pemanfaatan simbol metafora dalam pepatah-petitih Minangkabau? 
Melalui tulisan ini diharapkan dapat memberi konstribusi dalam (1) upaya melestarikan budaya berbahasa khususnya ragam bahasa simbolik yang mungkin saja bisa menghilang di tengah arus globalisasi yang melanda masyarakat, khususnya masyarakat Sumatera Barat (suku Minangkabau) ; (2) Melestarikan pepatah-petitih sebagai salah satu budaya berbahasa di Minangkabau yang cukup populer sebagai penghias kata-kata dalam berbagai situasi seremonial adat dan komunikasi formal maupun informal, (3) mengaktualkan pemahaman masyarakat terhadap falsafah 'Alam Terkembang Jadi Guru' sebagai salah satu aset budaya bangsa.

\section{Metode Penelitian}

Tulisan ini bersifat deskriptif-kualitatif karena bertujuan untuk mendeskripsikan "kondisi apa yang ada dalam situasi” (Ary.1979:415). Oleh karena itu, penelitian ini mengikuti prosedur rancangan penelitian deskriptif menggunakan pendekatan kualitatif. Prinsip penelitian kualitatif dalam penelitian ini dapat dilihat dari fokus penelitian yang bertujuan mengkaji makna, konsep, klasifikasi, identifikasi dari fenomena metafora yang ditemukan dalam pepatah-petitih Minangkabau. Metode yang digunakan adalah metode analisis isi (content analysis) yakni suatu metode penelitian untuk membuat inferensi-inferensi berdasarkan konteks yang melatarbelakangi pemunculan data penelitian. Desain analisis isi dalam penelitian ini meliputi beberapa langkah yakni, pengumpulan data, reduksi data/display data, penganalisisan, dan penarikan inferensi. 


\section{Bagan Alur Penelitian}

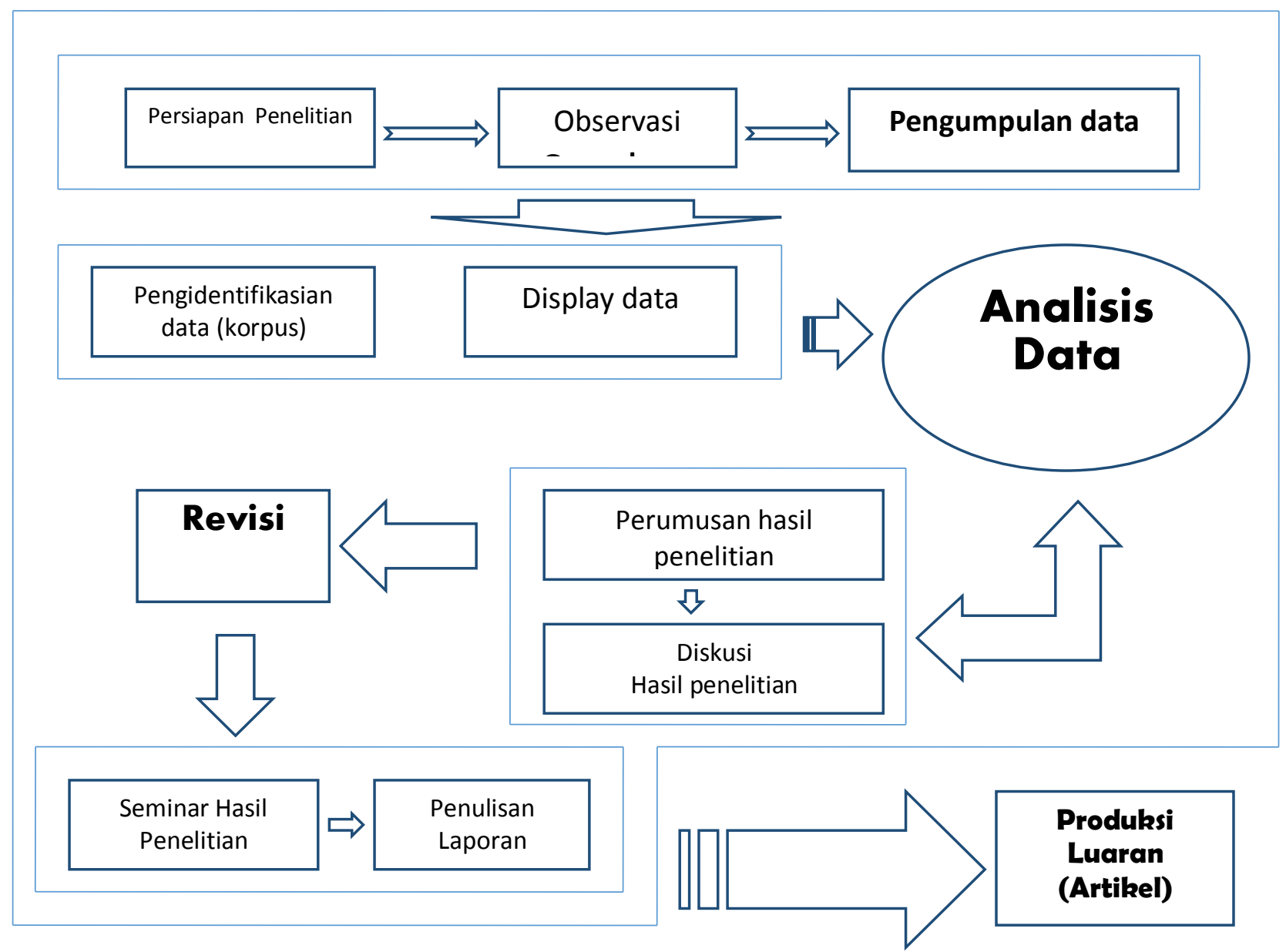

Data dalam penelitian ini adalah pepatah-petitih Minangkabau yang mengandung unsur metafora dengan memanfaatkan simbol-simbol yang bersumber dari lingkungan alam Minangkabau. Sumber data diperoleh melalui kumpulan Pepatah-petitih Minangkabau yang telah dibukukan oleh Yunus St. Majolelo (Pepatah-petitih Minangkabau, 1981), Yose Rizal Sidi Marajo (Peribahasa Minangkabau-Indonesia, 1995), Anas Nafis (Peribahasa Minangkabau, 1996).

Peneliti yang berada di tengah-tengah setting penelitian merupakan instrumen utama yang disebut dengan istilah human instrument (Samarin.1998). Dalam pengumpulan data, peneliti langsung terlibat (participant observer) karena pengumpulan data utama dalam penelitian kualitatif tidak lain adalah si pengamat peserta (participant observer).

Dalam penelitian ini, data penelitian sejumlah 218 korpus dikumpulkan melalui pendataan pepatah-petitih Minangkabau dari sumber data primer, yaitu buku-buku kumpulan pepatah- 
petitih yang sudah dipublikasikan dan beredar di kalangan masyarakat Minangkabau. Langkahlangkah yang dilakukan adalah:

a. Mengumpulkan data pepatah-petitih Minangkabau yang sudah dibukukan.

b. Memilah pepatah-petitih Minangkabau yang mengandung unsur metafora

c. Mengklasifikasikan pepatah-petitih Minangkabau sesuai dengan kebutuhan penelitian, yaitu data yang mengandung simbol-simbol metafora yang bersumber dari lingkungan alam Minangkabau.

d. Menganalisi data sesuai dengan pertanyaan penelitian.

e. Penarikan kesimpulan

Analisis data dilaksanakan setelah data terkumpul.Analisis data sesuai dengan rumusan masalah/pertanyaan penelitian yang sudah dikemukakan pada bagian terdahulu.Prinsip yang digunakan dalam analisis data adalah prinsip pendekatan analisis wacana dengan memanfaatkan piranti pengetahuan tentang dunia (knowledge of the world) dan interprestasi lokal (local interpratation) dan menempatkan konteks sebagai dasar analisis.

Prosedur analisis data sebagai berikut: (1) reduksi data, yakni merangkum data yang diperoleh dan memfokuskan pada hal-hal yang penting, (2) display data, mengidentifikasi data yang siap dianalisis, (3) mengambil kesimpulan serta (4) verifikasi (Moleong. 1990: 175-187).

\section{B. PEMBAHASAN}

1. Penggunaan Simbol Metaforadalam Pepatah Petitih Minangkabau yang Bersumberdari Lingkungan Alam Minangkabau

'Alam Terkembang Jadi Guru' merupakan falsafah adat yang tumbuh dan berkembang di bumi Minangkabau (Sumatera Barat). Sejauh ini, keberadaan falsafah tersebut dijadikan sebagai tolok ukur dalam bersikap dan bertingkah laku sehingga masyarakat tampak lebih dekat dengan alam serta lingkungannya. Kedekatan masyarakat dengan alam sekitar terlihat dari kekonsistenan masyarakat dalam memandang alam sebagai sumber pengetahuan dan sebagai guru dalam menata perilaku dan perbuatan.

Penelitian yang berjudul “Revitalisasi 'Alam Terkembang Jadi Guru' dalam Budaya Berbahasa di Minangkabau : Analisis Pemanfaatan Simbol Metafora dalam Pepatah-petitih Minangkabau" ini merupakan upaya pendeskripsian terhadap sejauhmana falsafah "Alam Terkembang Jadi Guru" diimplementasikan dalam kehidupan masyarakat, khususnya dalam 
budaya berbahasa masyarakat Minangkabau.Hubungan persepsi manusia dengan lingkungannya, telah dipetakan oleh Michael C. Haley, yang menyatakan bahwa hierarki ruang persepsi manusia meliputi konsep KE-ADA-AN, KOSMOS, ENERGI, SUBSTANSI, TERESTRIAL, BENDA, KEHIDUPAN, MAHLUK BERNYAWA, MANUSIA (Wahab.1991:66).

Kerangka konseptual yang menjadi acuan dalam penelitian ini berhubungan dengan rumusan masalah penelitian yang mencoba mendeskripsikan bagaimana implementasi falsafah 'Alam Terkembang Jadi Guru' dalam perilaku berbahasa di Minangkabau yang tercermin dalam pepatah-petitih yang berbentuk metafora. Secara spesifik kerangka konseptual penelitian ini adalah: (1) Pendeskripsian lambang kias metafora berdasarkan ruang persepsi manusia menurut Michael C. Haley. Ruang persepsi manusia yang mempengaruhi daya cipta manusia terhadap metafora dimulai dari lingkungan yang terdekat sampai ke lingkungan yang terjauh dan berlangsung secara hirarki. Hirarki ruang persepsi manusia tersebut terdiri dari: BEING, COSMOS, ENERGY, SUBSTANCE, TERRESTRIAL, OBJECT, LIVING, ANIMATE, HUMAN(Wahab 1991:86). Dalam penelitian ini, hirarki model Haley dijadikan dasar untuk memetakan hubungan yang sistematis antarlambang yang dipakai dalam metafora dan makna yang dimaksud.

Dalam penelitian ini peneliti memanfaatkan prinsip interpretasi local dan knowledge of the world untuk memahami ungkapan metafora, karena pemahaman terhadap suatu ujaran membutuhkan pemahaman terhadap budaya berpikir masarakat penuturnya. Oleh karena itu, pemanfaatan pengetahuan peneliti terhadap budaya berpikir masyarakat Minangkabau dijadikan dasar untuk menginterprestasikan makna suatu ungkapan sesuai dengan konteks suatu tuturan, dan mencoba menganalisis suatu bahasa yang digunakan secara alamiah.

Penggunaan lambang kias metafora dalam pepatah-petitih Minangkabau didasarkan atas kedekatan masyarakat Minangkabau dengan lingkungannya. Kedekatan tersebut merupakan wujud pemahaman masyarakat terhadap fenomena yang ada di lingkungan sekitar yang dapat dijadikan sebagai sarana untuk mewakili pemikiran, terutama dalam menyatakan sesuatu secara simbolik.Pemanfatan simbol-simbol yang diambil dari lingkungan, merupakan cerminan kedekatan manusia dengan lingkungannya masing-masing. Hal ini mengisyaratkan bahwa lingkungan yang berbeda akan menimbulkan pemahaman yang berbeda pula bagi masyarakatnya yang kemudian melahirkan bentuk tuturan yang berbeda pula. 
Pemanfaatan simbol metafora dalam pepatah-petitih Minangkabau, didasarkan atas hirarkhi ruang persepsi manusia terhadap lingkungannya. Hierarkhi tersebut meminjam sistematika yang telah diusulkan oleh Michael C. Haley (dalam Wahab:1991) yang telah memetakan ruang persepsi manusia berdasarkan kategori being, cosmos, energetic, substantial, terrestrial, object, living, animate dan human.

Distribusi pemanfaatan kategori ruang persepsi manusia dalam simbol metafora yang terdapat dalam pepatah-petitih Minangkabau, dapat dilihat dalam tabel berikut:

Tabel 1:

Distribusi Pemanfaatan Lambang Kias Metafora dalam Pepatah-petitih MInangkabau, Berdasarkan Kategori Ruang Persepsi Manuisa

\begin{tabular}{|l|c|}
\hline \multicolumn{1}{|c|}{ Kategori } & Jumlah Pemunculan \\
\hline Being & 12 \\
\hline Cosmos & 6 \\
\hline Energetic & 11 \\
\hline Substantial & 11 \\
\hline Terrestrial & 2 \\
\hline Object & 35 \\
\hline Living & 24 \\
\hline Animate & 24 \\
\hline Human & 93 \\
\hline
\end{tabular}

Berdasarkan tabel di atas terlihat kategori human merupakan simbol yang paling sering muncul dalam pepatah-petitih Minangkabau yang berbentuk metafora.Hal ini menunjukan bahwa manusia dengan segala aktivitasnya merupakan sumber inspirasi paling potensial bagi masyarakat Minangkabau dalam memahami segala aspek kehidupan di tengah masyarakat.Aktivitas serta perilaku masyarakat sering dijadikan sebagai sumber pengalaman untuk menciptakan simbol-simbol tertentu untuk mewakili maksud yang ingin disampaikan dalam sebuah tuturan.

Setelah kategori human, kelompok benda (object) berada di urutan kedua terbanyak yang muncul sebagai lambang kias dalam pepatah-petitih Minangkabau yang berbentuk metafora. Hal ini juga menyatakan bahwa benda-benda yang ada di sekitar kehidupan masyarakat Minangkabau sangat berpengaruh dalam perilaku berbahasa masyarakat Minangkabau. 
Temuan penelitian tentang keberagaman pemanfataan kategori object sebagai lambang kias dalam pepatah-petitih Minangkabau, membuktikan bahwa masyarakat Minangkabau sangat memahami sifat dan karakteristik benda-benda yang ada di lingkungan mereka. Hal inilah yang mendasari pemunculan simbol object sebagai upaya mencari bentuk lambang perbandingan yang tepat untuk menyatakan suatu maksud tertentu. Di samping itu, cerminan kedekatan masyarakat dengan hal-hal yang bersifat kebendaan terlihat jelas dengan ditemukannya beragam wujud benda dalam lambang kias yang digunakan.

Implikasi dari beragam dan banyaknya ditemukan lambang kias object dalam pepatahpetitih Minangkabau yang berbentuk metafora, mencerminkan kedekatan masyarakat dengan benda-benda yang adanya di sekeliling mereka. Keberadaan benda-benda yang ada dalam kehidupan masyarakat, tidak hanya dimanfaatkan sebagai penunjang aktivitas fisik atau sarana mempermudah dalam melakukan suatu pekerjaan saja, melainkan berperan pula dalam membentuk pola pikir yang kemudian tercermin dalam perilaku berbahasa.

Selanjutnya, secara berurutan kategori binatang (animate), tumbuhan (living), zat-zat energetic, benda-benda substansial, konsep abstrak (being), serta benda-benda cosmos dijadikan sebagai dasar pengambilan lambang-lambang kias dalam pepatah-petitih Minangkabau yang berbentuk metafora.

Kategori terakhir adalah kelompok terrestrial yang paling sedikit digunakan sebagai lambang kias dalam pepatah-petitih Minangkabau yang berbentuk metafora. Hal ini dimungkinkan karena keberadaan benda-benda terrestrial seperti samudera, laut, gunung, dan sungai, tidak mendapat perhatian khusus bagi masyarakat Minangkabau.

Distribusi pemanfaatan simbol metafora dalam pepatah-petitih Minangkabau seperti yang tertera pada tabel di atas membuktikan bahwa masyarakat Minangkabau memiliki kedekatan emosional yang sangat tinggi dengan segala sesuatu yang berhubungan dengan masyarakat serta aspek-aspek yang berhubungan langsung dengan aktivitas kemanusiaan. Sedangkan kategori terrestrial seperti hamparan yang terdapat di bumi, merupakan kelompok benda yang paling sedikit dimanfaatkan oleh masyarakat sebagai lambang kias dalam pepatah-petitih Minangkabau yang berbentuk metafora. Hal ini membuktikan bahwa hubungan serta pemahaman masyarakat terhadap kelompok benda-benda alam berupa hamparan yang terdapat di bumi, tidak terlalu mendapat perhatian khusus dalam pemikiran masyarakat Minangkabau, walaupun falsafah adatnya menyarankan belajar pada alam "Alam takambang jadi guru." 
Hasil penelitian ini juga menunjukkan adanya ketidakseimbangan pemikiran dan perhatian masyarakat Minangkabau terhadap alam sekitar mereka. Hal ini terlihat dari table persentase pemunculan lambang kias dalam pepatah-petitih Minanagkabau yang berbentuk metafora, berikut ini:

Tabel 2:

Persentase Pemanfaatan Lambang Kias Metafora dalam Pepatah-petitih MInangkabau, Berdasarkan Kategori Ruang Persepsi Manuisa

\begin{tabular}{|l|c|}
\hline \multicolumn{1}{|c|}{ Kategori } & Persentase Pemunculan \\
\hline Being & $5,5 \%$ \\
\hline Cosmos & $2,8 \%$ \\
\hline Energetic & $5 \%$ \\
\hline Substantial & $5 \%$ \\
\hline Terrestrial & $0,9 \%$ \\
\hline Object & $16,1 \%$ \\
\hline Living & $11 \%$ \\
\hline Animate & $11 \%$ \\
\hline Human & $42,7 \%$ \\
\hline
\end{tabular}

Persentase pemunculan lambang kias yang tidak merata seperti yang tertera dalam tabel di atas, membuktikan bahwa adanya ketidakseimbangan perlakuan dan perhatian masyarakat Minangkabau dalam memandang alam yang tersedia di lingkungan mereka. Dalam tabel di atas terlihat bahwa kategori human mencapai angka 93 kali pemunculan dari 218 pepatah-petitih yang dijadikan data penelitian ini. Dengan demikian sekitar 41,5\% penggunaan lambang kias metafora didasarkan atas kedekatan masyarakat terhadap perilaku dan aktivitas masyarakat. Selain kategori human, kategori object, animate, dan living juga sering digunakan sebagai lambang kias dalam pepatah-petitih Minangkabau yang berbentuk metafora. Hampir 38,1\% dari data yang terkumpul menggunakan ketiga kategori tersebut sebagai lambang kias. Dengan demikian, kategori hewan, binatang, dan hal-hal yang bersifat kebendaan merupakan kategori ruang persepsi yang terdekat dengan masyarakat Minangkabau. Sedangkan kategoriterrestrial, substansial, energetic, cosmos, dan being merupakan kategori yang jauh dengan kehidupan manusia atau tidak berhubungan secara langsung dengan aktivitas dan perilaku masyarakat sehari-hari. Hal ini dapat diketahui dari pemanfaatan simbol-simbol terrestrial, substansial, energetic, cosmos, dan being yang hanya mencapai 19,2\% dari keseluruhan data penelitian yang terkumpul. 
Perbedaan yang mencolok antara pemahaman dan perhatian masyarakat terhadap kategori ruang persepsi manusia, merupakan gambaran atas perilaku masyarakat yang tidak adil dalam memperlakukan lingkungan alam sekitar. Oleh karena itu, metafora sebagai ungkapan yang lahir dari pemahaman manusia terhadap lingkungannya, terutama dalam pemanfaatan simbol perbandingan untuk menyatakan sesuatu maksud tertentu, dapat dijadikan sebagai sarana untuk mengkaji sejauh mana kedekatan masyarakat dengan lingkungannya.

Berdasarkan uraian di atas, dapat ditarik berbagai temuan penelitian yaitu, sebagai berikut:

1. Masyarakat Minangkabau memiliki kedekatan emosional yang sangat tinggi serta keterikatan yang sangat kuat dengan segala sesuatu yang berhubungan dengan masyarakat serta aspekaspek yang berhubungan lansung dengan aktivitas masyarakat Minangkabau.

2. Perhatian masyarakat Minangkabau terhadap lingkungan sekitar terutama terhadap bendabenda alam berupa hamparan yang terdapat di bumi, kurang sekali . Hal ini terlihat dari pemanfaatan simbol terrestrial yang jarang ditemukan dalam pepatah-petitih Minangkabau yang berbentuk metafora.

3. Gambaran sikap masyarakat Minangkabau yang materialistik terlihat jelas dari pemanfaatan simbol object yang cukup sering muncul dalam pepatah-petitih Minangkabau. Seringnya muncul lambang objek dalam ungkapan pepatah-petitih merupakan realisasi dari kedekatan dan tingginya perhatian masyarakat terhadap hal-hal yang bersifat kebendaan. Hasil penelitian menunjukan bahwa pemahaman masyarakat Minangkabau terhadap benda-benda yang ada di sekeliling mereka di dasakan atas Fungsi, Sifat, Kondisi, Hubungan, Keadaan, Perilaku dari benda (object) 


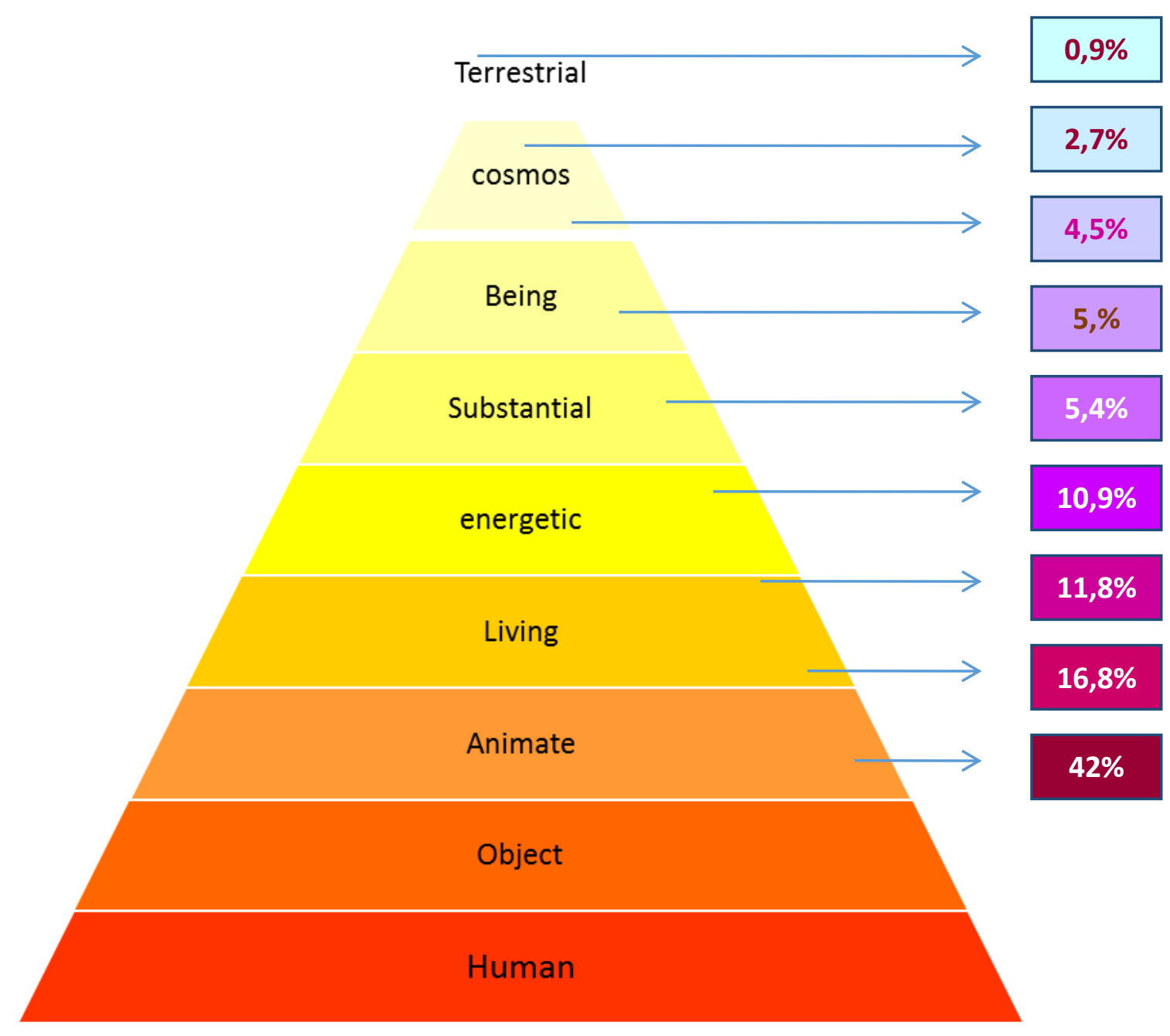

4. Masyarakat Minangkabau memiliki hirarkhi ruang persepsi yang berbeda dengan pendapat yang dikemukakan oleh Haley. Perbedaan tersebut terlihat dari distribusi pemanfaatan lambang kias metafora yang menunjukan bahwa secara hirarkhis urutan kedekatan manusia dengan berbagai kategori ruang persepsi manusia yang lain tidak sejalan dengan yang dikemukakan Haley.

Tabel 3

Perbandingan hierarkhi ruang persepsi masyarakat Minangkabau dengan masyarakat dunia lainnya

\begin{tabular}{|c|c|}
\hline Hierarkhi ruang persepsi masyarakat & Hirarkhi ruang persepsi manusia versi Haley \\
Minangkabau & Being \\
\hline Terrestrial & Cosmos \\
Cosmos & Energetic \\
Being &
\end{tabular}




\begin{tabular}{|c|c|}
\hline Substantial & Substantial \\
Energetic & Terrestrial \\
Living & Object \\
Animate & Living \\
Object & Animate \\
Human & Human \\
\hline
\end{tabular}

Berdasarkan perbandingan hirarkhi ruang persepsi manusia di atas, dapat disimpulkan bahwa masyarakat Minangkabau memiliki kekhasan tersendiri dalam memandang alam sekitarnya. Implikasi dari temuan penelitian ini menunjukan bahwa masyarakat Minangkabau memiliki pola pemikiran yang berbeda dari masyarakat dunia secara umum, terutama dalam memandang alam sekitar sebagai dasar pemikiran dalam penciptaan lambang kias metafora.

\section{PENUTUP}

Secara umum penelitian ini bertujuan mendapatkan gambaran tentang revitalisasi konsep 'Alam Terkembang Jadi Guru' dalam Budaya Berbahasa di Minangkabau. Dengan kata lain, penelitian ini berupaya mendeskripsikan sejauhmana falsafah "Alam Terkembang Jadi Guru" diimplementasikan dalam kehidupan masyarakat, khususnya dalam budaya berbahasa masyarakat Minangkabau. Ada tiga hal yang menjadi fokus penelitian ini, yaitu (1) penggunaan simbol metafora dalam pepatah petitih Minangkabau yang bersumber dari lingkungan alam Minangkabau, (2) deskripsi kedekatan masyarakat Minangkabau dengan alam sekitarnya, yang tercermin dalam pemanfaatan simbol metafora dalam pepatah-petitih Minangkabau, (3) keterkaitan falsafah 'Alam Terkembang Jadi Guru' dengan budaya berbahasa di Minangkabau melalui pemanfaatan simbol metafora dalam pepatah-petitih Minangkabau. Berdasarkan masingmasing fokus penelitian tersebut, dapat disimpulkan beberapa hal sebagai berikut.

1. Penggunaan lambang kias dalam pepatah-petitih Minangkabau yang berbentuk metafora, didasarkan atas kedekatan masyarakat dengan segala sesuatu yang ada di lingkungannya yang meliputi kategori being, cosmos, energetic, substantial, terrestrial, object, living, animate, dan human. Pengkategorian tersebut meminjam buah pikiran Michael C. Haley, yang telah memetakan ruang persepsi manusia mulai dari lingkungan yang paling jauh dari kehidupan manusia (being) sampai pada lingkungan terdekat dengan manusia yaitu kategori manusia itu sendiri (human). 
Sehubungan dengan penggunaan lambang kias dalam pepatah-petitih Minangkabau yang berbentuk metafora, berdasarkan temuan penelitian ini, dapat disimpulkan beberapa hal.

a. Adanya perbedaan urutan dari hierarki ruang persepsi manusia yang dikemukan oleh Haley dengan ruang persepsi masyarakat Minangkabau. Perbedaan terlihat dari urutan kedekatan masyarakat Minangkabau dengan berbagai kategori ruang persepsi yang dikemukakan Haley. Temuan penelitian menunjukkan bahwa kedekatan masyarakat dengan berbagai kategori ruang persepsi manusia, didasarkan atas seberapa sering masing-masing kategori ruang persepsi tersebut dimanfaatkan sebagai lambang kias dalam pepatah-petitih Minangkabau yang berbentuk metafora. Semakin sering masyarakat menggunakan suatu kategori ruang persepsi manusia sebagai lambang kias, menunjukan semakin dekat hubungan manusia dengan kategori ruang persepsi manusia tersebut. Berdasarkan asumsi tersebut, disimpulkan bahwa kategori human merupakan kategori ruang persepsi manusia yang terdekat dengan kehidupan masyarakat Minangkabau karena kategori manusia merupakan lambang kias yang paling sering digunakan sebagai lambang kias dalam pepatah-petitih Minangkabau. Selanjutnya, secara berurutan kedekatan hubungan masyarakat Minangkabau dengan kategori ruang persepsi lainnya ditempati oleh object, animate, living, energetic, substantial, being, cosmic. Urutan paling terakhir sebagai kategori yang memiliki hubungan terjauh dengan masyarakat Minangkabau, ditempati oleh kategori terrestrial.

Berdasarkan temuan tersebut, terdapat perbedaan dari hierarkhi hubungan masyarakat dengan kategori ruang persepsi manusia seperti yang telah dipetakan oleh Haley sebelumnya. Secara berurutan, hubungan masyarakat Minangkabau dengan kategori ruang persepsi manusia, dimulai dari human,object, animate, living, energetic, substantial, being, cosmic, dan terrestrial. Hal ini berbeda dengan urutan hierarkhi ruang persepsi manusia yang dipetakan Haley yaitu human, animate, living, object, terrestrial, substantial, energetic, cosmos, dan being.

a. Dengan kemunculan kategori human sebagai lambang kias dalam pepatah-petitih Minangkabau yang berbentuk metafora, sebanyak 93 kali atau sekitar 42,7\% dari keseluruhan data yang terkumpul, membuktikan bahwa masyarakat Minangkabau sangat peduli dan menaruh perhatian yang besar terhadap aspek kemasyarakatan dan hubungan sosial dalam kehidupan mereka sehari-hari.

b. Berdasarkan distribusi pemanfaatan kategori ruang persepsi manusia sebagai lambang kias dalam pepatah-petitih Minangkabau yang berbentuk metafora, terlihat bahwa tidak adanya 
keseimbangan perhatian masyarakat Minangkabau terhadap lingkungan alam yang tersedia di sekitar mereka. Hal ini dibuktikan dengan distribusi yang tidak merata dalam memanfaatkan alam sekitar sebagai lambang kiasnya yang terdapat dalam pepatah-petitih Minangkabau yang berbentuk metafora.

\section{DAFTAR PUSTAKA}

Ary, Donald.1979. Introduction to Research in Education. New York: Rinehard and Winston Levin, Samuel R. 1977. The Semantics of Metaphor. Baltimore: The John Hopkins University Levinson, Stephen C .1983. Pragmatics. London: Cambridge University Press

Lexy Moleong. 1990: Metodologi Penelitian Kualitatif. Bandung: Remaja Rosda Karya Nafis, Anas. 1996. Peribahasa Minangkabau. Jakarta: Intermasa

Rizal, Yose. 1996. Peribahasa Minangkabau Indonesia. Bandung: Pustaka Setia

Samarin, W. J. 1988.Ilmu Bahasa Lapangan. Jakarta: Kanisius

Wahab, Abdul. 1991. Isu Linguistik. Pengajaran Bahasa dan Sastra. Surabaya: Airlangga University Press

Yunus. 1981. Pepatah-petitih Minangkabau. Jakarta:Mutiara 